\title{
STRUKTUR KOMUNITAS ANOMURA (DEKAPODA) PADA KARANG MATI POCILLOPORA Spp. DI PULAU CEMARA BESAR KEPULAUAN KARIMUN JAWA KABUPATEN JEPARA
}

\author{
Eko Alfin Tirtana (1), Wahyu Andy Nugraha (2) \\ ${ }^{1}$ Mahasiswa Program Studi IImu Kelautan Universitas Trunojoyo Madura \\ ${ }^{2}$ Dosen Program Studi IImu Kelautan Universitas Trunojoyo Madura \\ Jl. Raya Telang No 02 Kamal Bangkalan Madura 69162
}

1Eko.alfin85@gmail.com

\begin{abstract}
ABSTRAK
Pulau Cemara Besar terletak di sisi timur Pulau Karimunjawa. Pulau Cemara Besar menjadi salah satu tujuan pulau wisata di Taman Nasional Karimunjawa dengan ekosistem terumbu karang yang masih alami. Dekapoda atau hewan berkaki sepuluh (udang, kepiting, dan lobster) merupakan salah satu hewan cryptofauna dimana beberapa spesies dekapoda ditemukan pada celah-celah karang. Penelitian ini dilaksanakan pada tanggal 16 - 26 maret 2017 di Pulau Cemara Besar Kepulauan Karimunjawa Kabupaten Jepara, Jawa tengah. Penelitian ini bertujuan untuk (1) Identifikasi jenis famili Anomura dan (2) Mendapatkan nilai struktur komunitas Anomura. Pengambilan decapoda dilakukan dengan beebrapa tahapan yaitu penggambilan biota, pemisahan, pengawetan dan identifikasi. Berdasarkan hasil penelitian didapatkan 3 famili yaitu Diognidae, Porcellinidae, dan Galatidae. Kepadatan tertinggi pada karang 4 pada famili Porcelinidae sebesar 8,49 dan kepadatan terkecil pada karang 8, famili Porselinidae sebesar 0,27. Hasil Perhitungan Struktur Komunitas didapatkan keseragaman $\left(\mathrm{H}^{\prime}\right)$ tertinggi pada karang 8 dengan nilai sebesar 0,94. Nilai indeks keseragaman (E) tertinggi pada karang 4 dengan nilai 0,97 . indeks dominansi (D) tertinggi pada karang 2, 3, dan 7 dengan nilai 1.
\end{abstract}

Kata Kunci : Struktur Komunitas, Dekapoda, Anomura, Pulau Cemara Besar

\section{PENDAHULUAN}

Pulau Cemara Besar terletak di sisi timur Pulau Karimunjawa. Pulau Cemara Besar menjadi salah satu tujuan pulau wisata di Taman Nasional Karimunjawa, jernihnya air laut, pasir putihnya ditambah lagi dengan terumbu karang yang masih alami dan indah menjadi daya tarik wisatawan lokal maupun wisatawan luar negeri, sehingga perlu dilakukan penelitian terkait struktur komunitas dekapoda dengan banyaknya pengunjung dan wisatawan.

Dekapoda atau hewan berkaki sepuluh (udang, kepiting, dan lobster) merupakan salah satu hewan Cryptofauna dimana beberapa spesies dekapoda ditemukan pada celah-celah karang baik karang mati maupun karang hidup. Cryptofauna adalah invertebrata makro dan beberapa ikan yang menggunakan rongga di substrat baik sementara atau permanen. Beberapa dapat menciptakan rongga mereka sendiri pada terumbu karang, sedangkan yang lain merupakan penjajah oportunistik ruang yang ada (Hutchings 1983).

Cryptofauna merupakan bagian penting dari jaring makanan pada ekosistem terumbu karang. Organisme cryptofauna merupakan sumber makanan penting untuk karnivora karang tertentu, termasuk ikan, gastropoda, moluska dan gurita. Penelitian ini difokuskan pada ordo dekapoda. Ordo dekapoda ini yang diambil dari infra ordo Anomura. Infra ordo ini terdapat sedikit informasi, sehingga pemilihan ini dilakukan untuk 
menambah informasi terkait infra ordo Anomura.

Karang hidup dan mati memberikan kondisi yang sangat berbeda untuk biota asosiasi. Karang hidup menyediakan berbagai sumber makanan potensial untuk biota yang berukuran besar. Namun, karang mati dapat memberikan keragaman yang lebih besar dari sumber daya makanan daripada karang hidup seperti, crustose berkapur, lumut, lamun, bryozoa, spons, dan foraminiferan. Karang mati mempunyai proporsi yang besar pada substrat terumbu karang dimana celah atau ruang yang terdapat pada karang mati dapat dimanfaatkan oleh berbagai biota asosiasi sebagai tempat tinggal.. Rata-rata jumlah individu cryptofauna pada karang mati Pocillopora damicornis sebanyak 135,4 individu dan pada karang hidup Pocillopora damicornis sebanyak 72,8 individu. Maka dari itu bisa diasumsikan bahwa keanekaragaman hayati akan lebih banyak ditemukan pada karang mati dibandingkan karang yang masih hidup
(Enochs \& Hockensmith 2008).

Penelitian ini bertujuan untuk:

1. Melakukan identifikasi famili Anomura di Pulau Cemara Besar.

2. Mengetahui struktur komunitas Anomura di Pulau Cemara Besar.

3. Mengetahui hubungan famili Anomura dengan karang mati

\section{METODE PENELITIAN Waktu dan Tempat Penelitian}

Penelitian ini dilaksanakan pada tanggal 16 - 26 Maret 2017, pengambilan karang mati dilakukan di Pulau Cemara Besar Kepulauan Karimunjawa Kabupaten Jepara, Jawa tengah. Pulau Cemara Besar merupakan pulau tak berpenghuni yang mempunyai luas 3,5 ha. Pulau Cemara Besar menjadi salah satu tujuan pulau wisata di Taman Nasional Karimunjawa. Stasiun pengamatan pada penelitian ini terdiri dari 1 stasiun dimana dalam stasiun tersebut diambil 8 sampling karang mati Pocillopora.

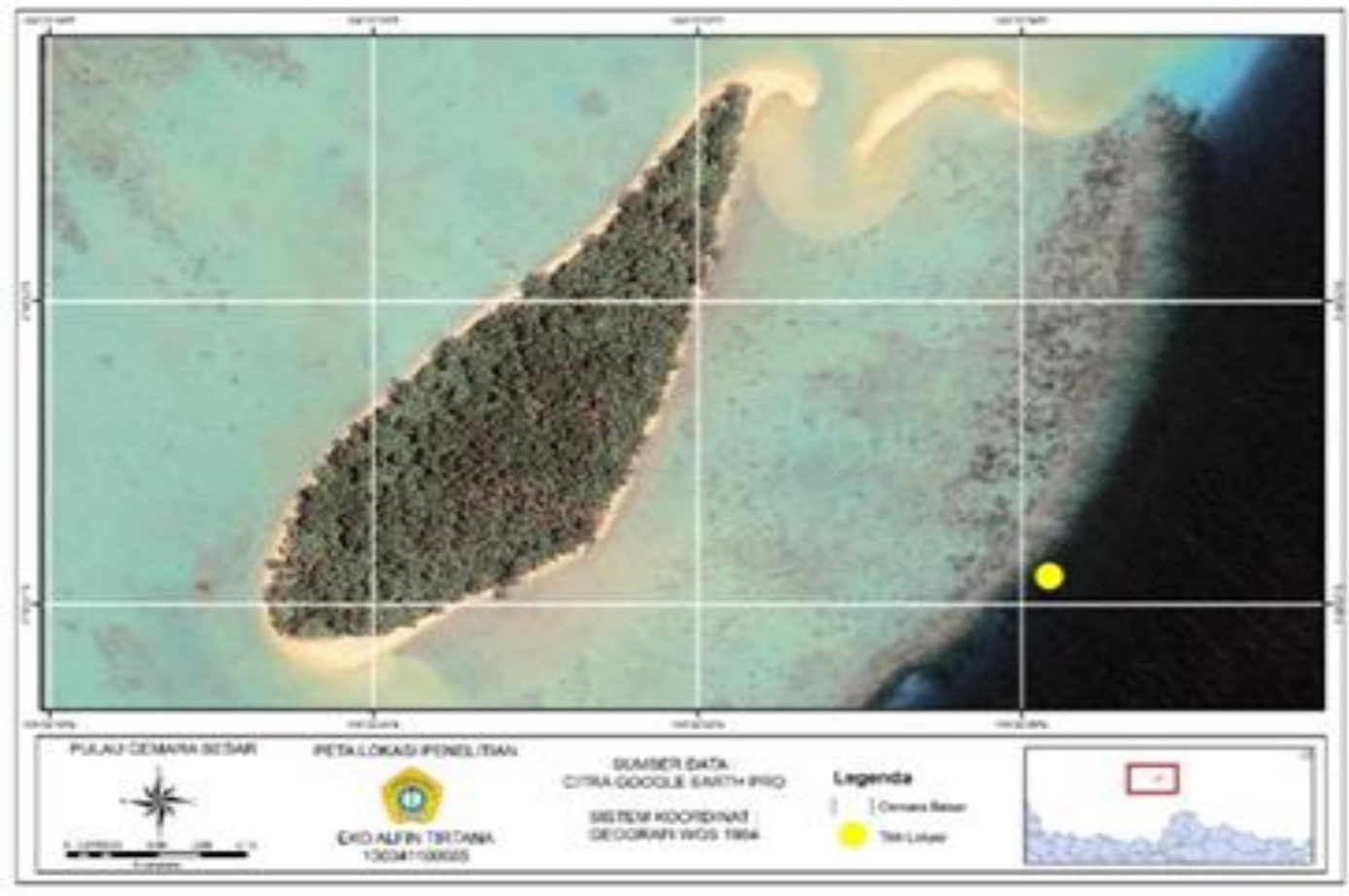

Gambar 1. Pulau Cemara Kepulauan Karimunjawa Kabupaten Jepara Jawa Tengah 


\section{Pengambilan Sampel Karang}

Pengambilan sampel karang mati Pocillopora menggunakan peralatan selam, pahat, palu, ember, dan kantong plastik. Pahat dan palu digunakan untuk melepaskan karang dari substrat, kemudian karang mati dibungkus dengan kantong plastik agar biota yang terdapat pada sampel tidak keluar pada saat dipindahkan ke ember. Sampel karang mati yang diambil terdiri dari 10 karang mati Pocillopora, karang mati yang telah dibawa ke darat harus segera diberi airator guna mencegah kematian biota yang terdapat pada karang mati tersebut.

Pengukuran panjang, lebar, tinggi karang mati dilakukan menggunakan meteran, dan pengukuran volume karang mati di ukur dengan menggunakan wadah ember dan gelas ukur, dimana volume karang mati sama dengan volume air yang tumpah apabila karang dimasukkan.

\section{Pengambilan Sampel Dekapoda}

Untuk mengambil sampel dilakukan pemecahan sampel karang mati. untuk mempermudah pengambilan biota yang kemudian disortir dengan menggunakan cup plastik per individu dan diberikan label dengan menggunakan kertas karkil pada setiap cup plastik. Selanjutnya, dilakukan identifikasi sampai pada taksa famili dengan menggunakan buku identifikasi (Debelius 2001)

Tahap selanjutnya adalah pemingsanan biota dengan menggunakan minyak cengkeh. Biota yang sudah di sortir dan dipingsankan akan diletakan pada cawan petri yang telah diisi air dan didasari oleh kain hitam supaya mendapatkan foto dengan kualitas warna yang kontras. Selanjutnya akan dilakukan pengambilan data menggunakan kamera resolusi tinggi.

Tahap akhir adalah koleksi biota dimana pada tahap ini biota yang telah melewati tahap dokumentasi akan dimasukan kedalam tube atau botol sampel yang berisi ethanol $96 \%$. Identifikasi lanjutan dengan melihat foto dan sampel dengan menggunakan buku identifikasi.

\section{Analisis Data}

a) Kepadatan

Kepadatan Anomura dihitung menggunakan rumus dalam odum (1993), yaitu $\sum_{X=\frac{X}{n}}$

Dimana :

$$
\begin{array}{ll}
\mathrm{X} & \text { : Kepadatan dekapoda } \\
\mathrm{Xi} & \text { : Jumlah individu (Dekapoda) } \\
\mathrm{n} & \text { : Volume }
\end{array}
$$

Tabel 1. Klasifikasi Nilai Indeks Keanekaragaman

\begin{tabular}{|c|c|}
\hline Nilai Keseragaman & Keterangan \\
\hline $\mathrm{E}<0,4$ & $\begin{array}{l}\text { Indeks keseragaman mendekati nilai } 0 \text { maka keseragaman akan } \\
\text { semakin rendah. Keseragaman kurang dari } 0,4 \text { maka keseragaman di } \\
\text { kategorikan rendah. }\end{array}$ \\
\hline $0,4 \leq \mathrm{E} \leq 0,6$ & $\begin{array}{l}\text { Indeks keseragaman kurang dari atau samadengan } 0,6 \text { dan nilai } \\
\text { indeks keseragaman makrozoobenthos yang ditemukan atau } \\
\text { didapatkan dari hasil perhitungan lebih besar atau sama dengan } 0,4 \\
\text { maka dapat dikatakan sedang. }\end{array}$ \\
\hline$E>0,6$ & $\begin{array}{l}\text { Indeks keseragaman yang ditemukan dalam perhitungan lebih dari 0,6 } \\
\text { maka indeks keseragaman makrozoobenthos di perairan tersebut } \\
\text { tinggi. }\end{array}$ \\
\hline
\end{tabular}

\begin{tabular}{cllll}
\hline Nilai Keanekaragaman & \multicolumn{4}{c}{ Keterangan } \\
\hline$H^{\prime}<1,0$ & Keragaman rendah, penyebaran tiap spesies rendah dan \\
& kestabilan komunitas rendah & & & \\
$1,0<H^{\prime}<3,0$ & Keragaman sedang, penyebaran tiap spesies sedang dan \\
& kestabilan komunitas sedang & & \\
$H^{\prime}>3,0$ & Keragaman tinggi, penyebaran tiap spesies tinggi dan kestabilan \\
& komunias tinggi.
\end{tabular}

Tabel 2. Klasifikasi Nilai Indeks Keseragaman 


\section{b) Keanekaragaman}

Perhitungan keanekaragaman jenis ini dilakukan dengan menggunakan indeks Keanekaragaman Shannon-Wiener.

$$
H^{\prime}=-\sum_{i-1}^{s} P i \log P i
$$

Dimana :

$\mathrm{H}^{\prime}$ : indeks keanekaragaman

$\mathrm{Pi} \quad: \mathrm{ni} / \mathrm{N}$

$\mathrm{N}$ : jumlah total individu seluruh jenis

$\mathrm{Ni} \quad$ : jumlah individu jenis ke-i

\section{c). Keseragaman}

Indeks Keseragaman digunakan untuk menggambarkan komposisi individu setiap spesies yang terdapat dalam satu komunitas, yang dihitung dengan menggunakan rumus Evenness sebagai berikut (Bengen 2000) :

Dimana :

$$
E=\frac{H^{\prime}}{\ln S}
$$

$$
\begin{array}{ll}
\mathrm{E} & : \text { indeks keseragaman } \\
\mathrm{H}^{\prime} & : \text { indeks keanekaragaman } \\
\mathrm{H} \max & : \text { log } \mathrm{S} \\
\mathrm{S} & : \text { jumlah jenis }
\end{array}
$$

\section{d). Indeks Dominasi (Simpson)}

Nilai indeks dominasi digunakan untuk menggambarkan ada tidaknya dominansi suatu jenis dalam satu komunitas. Perhitungan indeks dominansi Simpson sebagai berikut :

Keterangan :

$$
\mathrm{C}=\sum_{\mathrm{i}=1}^{\mathrm{s}}\left(\frac{\mathrm{ni}}{\mathrm{N}}\right)^{2}
$$

C : indeks Dominansi

$\mathrm{Ni} \quad$ : jumlah individu tiap spesies

$\mathrm{N} \quad$ : jumlah total individu $\mathrm{i}$ seluruh spesies

Dengan kreteria :

$0,00<\mathrm{C} \leq 0,50$ : Dominansi rendah

$0,50<C \leq 0,75$ : Dominansi sedang

$0,75<\mathrm{C} \leq 1,00$ : Dominansi tinggi

\section{HASIL DAN PEMBAHASAN}

\section{Gambaran Umum Lokasi Penelitian}

Pulau Cemara Besar terletak pada

sisi timur Pulau Karimunjawa. Lebih tepatnya Pulau Cemara Besar terletak di laut Jawa sebelah utara Pulau Jawa. Akses menuju pulau ini ditempuh dengan menggunakan kapal feri selama $4-5$ jam dari pelabuhan Jepara menuju Pulau Karimunjawa. Pulau Karimunjawa menuju Pulau Cemara Besar ditempuh dengan menggunakan kapal nelayan selama 30 45 menit. Luas Pulau Cemara Besar mencapai 3,5 ha dan tidak berpenghuni.

\section{Jenis Anumora di Cemara Besar}

Berdasarkan hasil pengamatan famili Anumora di Pulau Cemara Besar terdiri dari 3 famili yaitu: Porcelinidae, Galatidae, dan Dioginidae.

\section{Porcelinidae (Poore, 2004)}

Kingdom : Animalia

Filum : Arthropoda

Kelas : Crustacea

Ordo : Dekapoda

Infra ordo :Anomura

Famili : Porcelinidae

Famili Porcellinidae memiliki ciri ciri antara lain : (1) posisi mata berada di tengah tengah antenna; (2) memiliki rektum pendek atau tidak ada; (3) memiliki antena yang panjang; (4) memiliki celipet yang panjang (Carpenter dan Volker 1998)

\section{Galatidae (Poore 2004)}

Kingdom : Animalia

Filum : Arthropoda

Kelas : Crustacea

Ordo : Dekapoda

Infra ordo :Anomura

Famili : Galatidae

Famili Galatidae memiliki ciri ciri antara lain : (1) Posisi mata berada di tengah tengah antenna; (2) Berbentuk seperti lobster yang sedang berjongkok; (3) Memiliki perut yang melengkung dan berduri; (4) Memiliki celipet sangat panjang (Carpenter dan Volker 1998). 

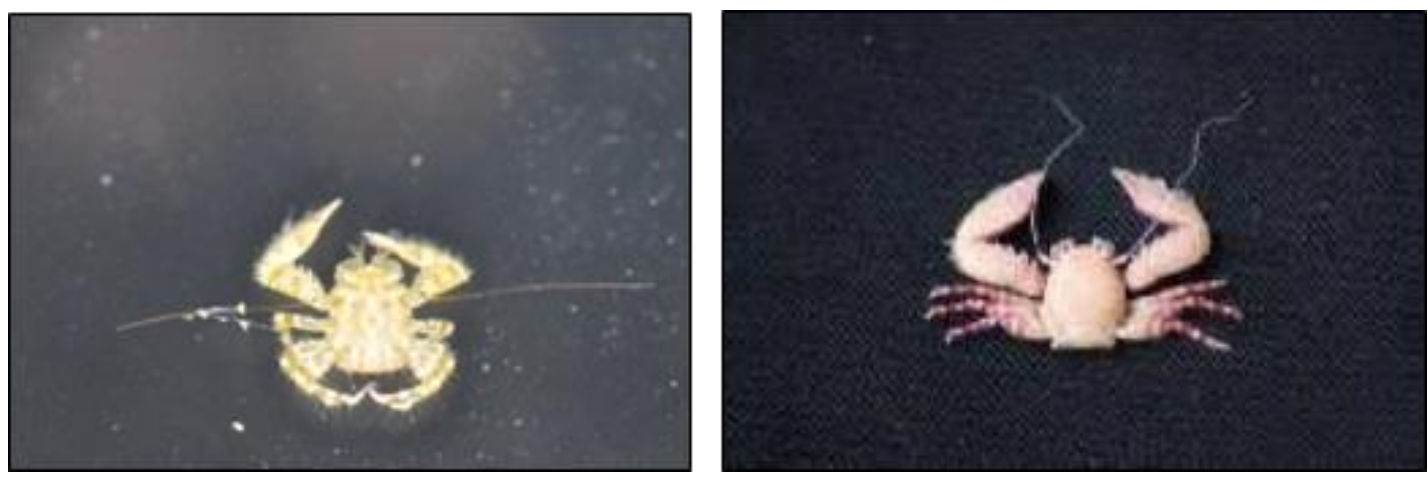

Gambar 2. (A) Porcelinidae (pada penelitian), (B) Porcelinidae (pada Santoso 2013)
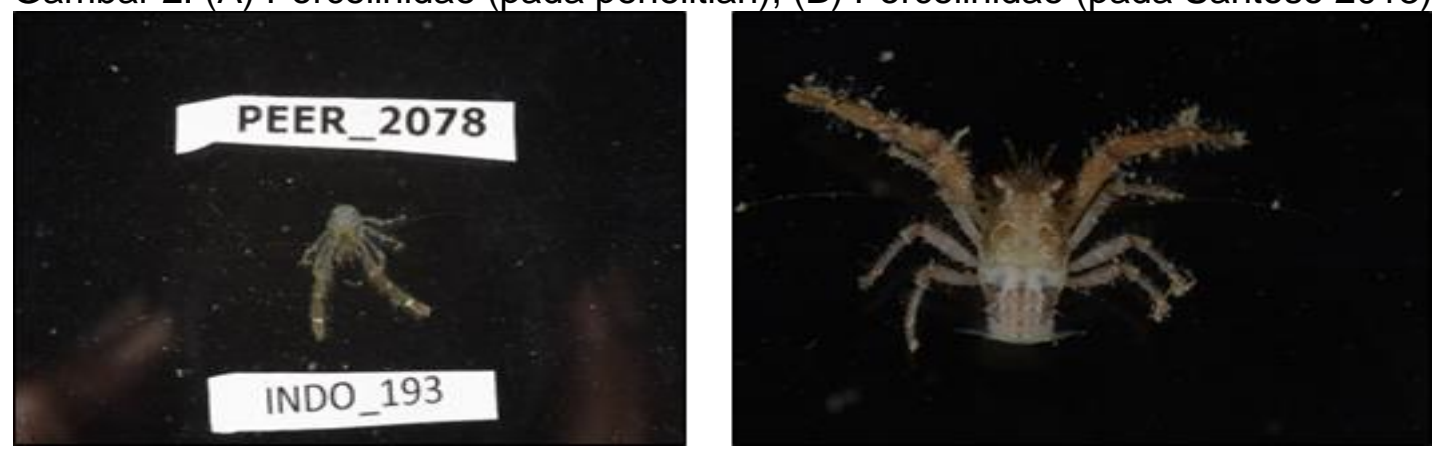

Gambar 3. (A) Galatidae (pada penelitian), (B) Galatidae (pada Santoso 2013)

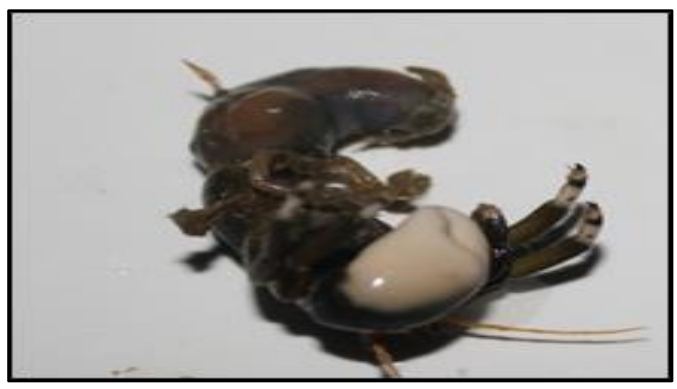

Gambar 4. Diognidae (pada penelitian)

\section{Dioginidae (Poore 2004) \\ Kingdom : Animalia \\ Filum : Arthropoda \\ Kelas : Crustacea \\ Ordo : Dekapoda \\ Infra ordo :Anomura \\ Famili : Dioginidae}

Famili Draginidae memiliki ciri ciri antara lain : (1) Posisi mata berada di tengah tengah antenna; (2) Memiliki capit kiri lebih besar dibandingkan dengan capit kanan dan terkadang sama; (3) Wopet tidak berbentuk ekor (Carpenter dan Volker 1998).

Berdasarkan dari Tabel 3 menunjukkan bahwa pada karang 1 famili yang ditemukan diantaranya adalah Porcelinidae dan Galatidae. Jumlah famili paling banyak yang ditemukan pada karang 1 adalah Porcelinidae sebanyak 16 individu dan Galatidae sebanyak 5 individu. Berbeda dengan karang ke 2 dan ke 3 yang ditemukan hanya famili Galatidae 
Famili tersebut berturut - turut memiliki jumlah sebanyak 8 individu dan 2 individu. Famili Galatidae dan Porcelinidae ditemukan pada karang 4, 5, dan 6, sementara famili Porcelinidae ditemukan pada karang ke 7 . Karang 8 ditemukan 3 famili anumora, famili tersebut dua diantaranya adalah dari jenis Galatidae dan Porcelinidae. Karang ke 8 selain tedapat dua jenis tersebut ditemukan juga famili yang tidak ditemukan pada karang lainnya yaitu dari famili Dioginidae. Jumlah famili Galatidae yang ditemukan pada karang ke 4,5 dan 6 berturut - turut sebanyak 6 individu, 4 individu, dan 1 individu. Berbeda pada famili porcelinidae sebesar 9 individu, 1 individu, dan 8 individu. Karang 7 hanya ditemukan famili Porcelinidae sebanyak 1 individu. Karang 8 terdapat 3 jenis yaitu Porcelinidae sebanyak 1 individu, Galatidae sebanyak 4 individu, dan Dioginidae sebanyak 5 individu.

Berdasarkan dari tabel diatas indeks keseragaman $\left(\mathrm{H}^{\prime}\right)$ tertinggi pada karang 8 sebesar 0,94, sedangkan nilai indeks keanekaragaman $\left(\mathrm{H}^{\prime}\right)$ terendah ada pada karang 2, 3, dan 7 dengan nilai 0 . Nilai indeks keseragaman (E) tertinggi pada karang 4 dengan nilai 0,97 , sedangkan nilai terendah terdapat pada karang 2, 3 , dan 7 dengan nilai 0 . Nilai indeks dominansi (D) tertinggi pada karang 2, 3 , dan 7 dengan nilai 1 . Nilai indeks dominansi terendah pada karang 5 dengan nilai 0,52 .
Kelimpahan tertinggi famili dekapoda yang ditemukan di lokasi perairan Pulau Cemara Besar Keplauan Karimunjawa yaitu famili Galatidae mempunyai kelimpahan yang besar karena banyak ditemukan pada setiap karang mati Pocillopora sp. yang ditemukan pada lokasi penelitian. Hal ini diperkuat dengan Patton (1964), yang menyebutkan bahwa organisme dari famili tersebut paling umum ditemukan pada karang yang mempunyai bentuk petumbuhan bercabang atau branching (Patton, 1964) dan merupakan organisme pemakan alga atau bersifat detritus (Poore, 2004).

Karena ketika karang telah mati maka karang akan ditumbuhi oleh tumbuhansesil (crustose berkapur dan lumut, serta faunaseperti bryozoan, sponge, dan foraminiferan) yang menjadi sumber makanan bagi dekapoda (Enochs dan Hockensmith, 2008). Hal ini akan menjadi makanan yang baik untuk famili Galathidae.(Wicksten, 1993).

Tingkat stress atau tekanan oleh lingkungan yang diterima biota penyusun (Lardicci et al., 1997), dan keseimbangan jenis biota penyusun dalam lingkungannya disuatu komunitas dapat dilihat dengan menggunakan nilai indeks keanekaragamanan. Ukuran indeks keanekaragaman yang mengacu pada (Kerbs, 1985) menyatakan bahwa, indeks keanekaragaman dibawah $1 \quad\left(H^{\prime}<1\right)$ tergolong rendah; antara 1 sampai $3\left(\mathrm{H}^{\prime}\right.$

Tabel 3. Jumlah Famili Anomura yang Ditemukan

\begin{tabular}{ccc}
\hline Karang & Famili & Jumlah \\
\hline 1 & Porcelinidae & 16 \\
2 & Galatidae & 5 \\
3 & Galatidae & 8 \\
4 & Galatidae & 2 \\
& Galatidae & 6 \\
5 & Porcelinidae & 9 \\
& Galatidae & 4 \\
7 & Porcelinidae & 1 \\
& Galatidae & 1 \\
& Porcelinidae & 8 \\
& Porcelinidae & 1 \\
& Galatidae & 4 \\
\end{tabular}


1-3) tergolong sedang; dan lebih dari 3 $\left(H^{\prime}>3\right)$ tergolong tinggi atau stabil. penyebaran individu setiap spesies, serta stabilitas komunitas yang rendah. Nilai keanekaragaman filum Anomura dalam penelitian ini menunjukkan nilai $0-0,94$ yang tergolong rendah.

Kondisi suatu lingkungan perairan dapat ditentukan melalui indeks keanekaragaman. Menurut Wedaningsih (2005) banyaknya spesies dalam suatu komunitas dan kelimpahan dari masing masing spesies tersebut menyebabkan semakin kecil jumlah spesies. Selain itu variasi jumlah individu dari tiap spesies atau ada beberapa individu yang jumlahnya lebih besar, juga menyebabkan keanekaragaman suatu ekosistem akan mengecil.

Nilai indeks keseragaman ini menggambarkan keseimbangan ekologis pada suatu komunitas, dimana semakin tinggi nilai keseragaman maka kualitas lingkungan semakin baik. Keseragaman pada lokasi penelitian diperoleh kisaran nilai 0 sampai 0,97 . Hasil pengamatan menunjukkan bahwa lingkungan perairan laut Pulau Cemara Besar berada dalam kisaran baik, karena secara keseluruhan nilai keseragaman pada setiap stasiun pengamatan sangat beragam dengan sebaran merata. Gunarto (2004) mengatakan hal ini menggambarkan bahwa sebaran dari krustasea di daerah tersebut relatif bervariasi, tergantung kondisi lingkungan alamnya.

Krustacea sebagai hewan bentik hidupnya sangat tergantung pada subtrat atau karang sebagai tempat hidup dan tempat mencari makan yang berupa detrius atau sesil. Dengan adanya kondisi yang mengganggu di habitatnya, maka jenis yang tidak mampu beradaptasi akan menghilang, sementara jenis yang mempunyai ketahanan yg tinggi akan mendominasi (Pratiwi 2002)

Indeks dominansi digunakan untuk melihat adanya jenis tertentu yang mendominasi disuatu komunitas (Odum, 1993). Pada lokasi penelitian memiliki nilai dominansi $1-0,42$ yang menunjukkan adanya famili tertentu dari dekapoda yang mendominasi pada komunitas tersebut. Indeks keseragaman dilokasi penelitian menunjukkan komunitas dilokasi tersebut menunjukkan komunitas yang labil. Hal ini dikarenakan adanya famili dari Galatidae yang sangat melimpah dibandingkan dengan famili lainnya. Odum (1993), jika ada suatu jenis menunjukkan jumlah yang tinggi dibandingkan jenis lainnya yang ditemukan akan menghambat perkembangan jenis lainnya dalam suatu ekosistem.

Tabel 4. Jumlah Famili Anomura yang Ditemukan
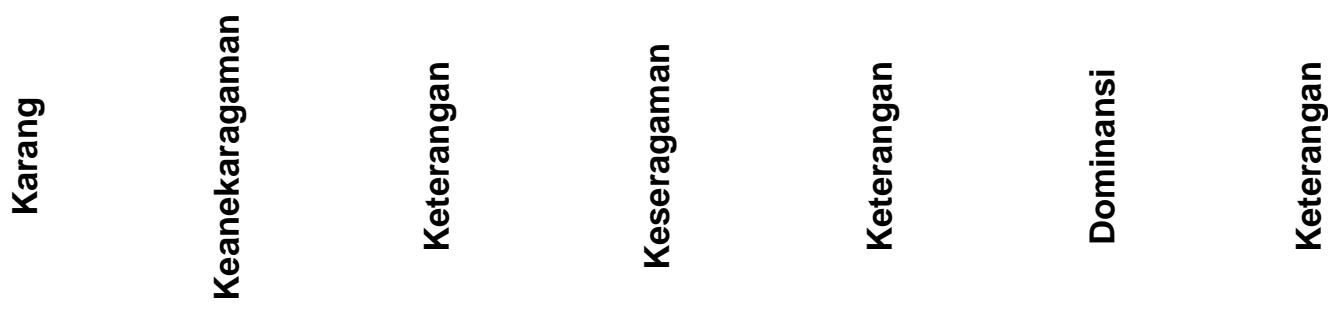

\begin{tabular}{ccccccc}
\hline 1 & 0,57 & Rendah & 0,82 & Tinggi & 0,64 & Sedang \\
2 & 0 & Rendah & 0 & Rendah & 1 & Tinggi \\
3 & 0 & Rendah & 0 & Rendah & 1 & Tinggi \\
4 & 0,67 & Rendah & 0,97 & Tinggi & 0,52 & Sedang \\
5 & 0,50 & Rendah & 0,72 & Tinggi & 0,68 & Sedang \\
6 & 0,35 & Rendah & 0,50 & Sedang & 0,80 & Tinggi \\
7 & 0 & Rendah & 0 & Rendah & 1 & Tinggi \\
8 & 0,94 & Rendah & 0,86 & Tinggi & 0,86 & Tinggi \\
\hline
\end{tabular}


Namun Putri et al, (2012) menyebutkan jika nilai keseragaman lebih dari 0.6 (E>0.6) menunjukkan bahwa komunitas organisme didaerah tersebut masih tergolong dalam komunitas yang stabil. Hubungan korelasi antara volume karang mati dengan jumlah dekapoda yaitu memiliki korelasi positif dan memiliki hubungan yang sangat rendah dengan nilai $(r=0.172)$ dengan volume karang mati yang ditemukan di lokasi penelitian.

Berdasarkan kriteria korelasi Sarwono (2006) jumlah dekapoda memiliki hubungan sangat rendah. Pada karang mati ditemukan paling banyak dari Famili Brachyura karena memiliki capit yang kuat sehingga mampu berkompetisi, sementara dari Famili Anomura sedikit yang ditemukan. Hubungan rendah ini dikarenakan beberapa faktor salah satunya dari makanan. Anomura merupakan hewan karnivora akan tetapi dalam keadaan tertentu anomura dapat memakan segalanya atau omnivora (UNESCO 2007). Faktor lain yang menyebabkan hubungan rendah dikarenakan dalam karang mati terdapat beberapa famili lain yang tinggal disana. Famili yang tinggal di dalam karang mati seperti Brachyura, dan Caridea. Keberadaan famili lain dalam karang mati menyebabkan terjadinya kompetisi Kompetisi yang terjadi di dalam karang mati membuat keberadaan Anomura menjadi terganggu. Anomura yang ditemukan pada karang mati saat penelitian tidak banyak, hanya sebagian kecil dari total biota yang ditemukan.

\section{KESIMPULAN}

Dari hasil penelitian tersebut dapat diperoleh kesimpulan sebagai berikut :

1. Anomura yang ditemukan pada lokasi penelitian yakni dari filum Porcelinidae, filum Galatidae, dan filum Dioginidae

2. Anomura yang ditemukan pada lokasi tersebut memiliki kelimpahan yang beragam pada volume karang yang berbeda.

3. Keanekaragaman Anomura secara keseluruhan di lokasi penelitian tergolong rendah dengan nilai 0 sampai 0,94 yang berarti keragaman rendah, penyebaran tiap spesies rendah dan kestabilan komunitas rendah. Nilai keseragaman Anomura pada lokasi penelitian berkisar 0 sampai 0,97. Berarti sebaran Anomura di daerah tersebut relatif merata sedangkan nilai indek dominasi Anomura berkisar 1 sampai 0,42 . Secara keseluruhan nilai dominasi mendekati nilai 1 yang berarti adanya dominasi dari salah satu ada yang mendominasi.

4. Banyaknya jumlah Anomura yang ditemukan di lokasi penelitian dipengaruhi oleh besarnya ukuran volume karang mati Pocillopora sp. yang ditemukan.

\section{DAFTAR PUSTAKA}

Asian. R., Said.R.T., Waty. L. Z., 2015. Struktur Komunitas Decapoda di Perairan Kampung Bugis Kelurahan Kampung Bugis Kecamatan Tanjungpinang Kota. ( di akses Tanggal $15 \quad$ November 2017 http.www//jurnal.umrah.ac.id)

Bengen, D. G. 2000. Teknik Pengambilan Contoh dan Analisis Data Biofisik Sumber Daya Pesisir. Fakultas Perikanan dan IImu Kelautan. Institut Pertanian Bogor.

Carpenter,K.E., Niem, V.H. 1998. Species Identification Guide for Fishery Purposes. The Living Marine Resuuces of The Western Central Pasific. Volume 2. Cephalopods, Crustaceans, Holothurians And Sharks. FAO.

Dahuri, R, J. Rais, S.P. Ginting, dan M.J. Sitepu. 2001. Pengelolaan Sumberdaya Pesisir dan Lautan Secara Terpadu. Cetakan kedua. Pradnya Paramita. Jakarta. 326 p.

Debelius H. 2001. Crustacea Guide of The Wolrd. Frankfurt. 
Dian et, al. 2005. Identifikasi Sand Dollar dan Karakteristik Habitatnya di Pulau Cemara Besar, Kepulauan Karimunjawa Jepara. IImu Kelautan. 10 (1) : 1-10. 0853 - 7291 Enochc, I. J dan G. Hockensmith. 2008. Effects of Coral Mortality on The Community Composition of Cryptic Metazoans Associated with Pocilloporadamicornis. University of Miami. RSMAS. 4600 Rickenbacker Cswy. Miami.

Hartati, S.T. dan Indar, S.W. 2003. Kepadatan, Keanekaragaman, dan Lingkungan Teripang di Gugusan Pulau Kelapa. Jurnal

Penelitian Perikanan Indonesia. Vol 9 No. 7. $49-57$.

Hutchings, P. A. 1983. Cryptofaunal Communities of Coral Reefs. In: Barnes DJ (Ed) Perspectives On Coral Reefs. Australian Institute of Marine Science. Townsville. Australia. pp 200208

Johan O. 2000. Tingkat keberhasilan transplantasi karang batu di Pulau Pari, Kepulauan Seribu, Jakarta [Tesis]. Program Pasca Sarjana, Institut Pertanian Bogor. Bogor. 89 hlm.

Muchammad, M. U. Widaningsih. Retno, H. 2012. Komposisi dan Kelimpahan Makrozoobenthos Krustasea di Kawasan Vegetasi Mangrove Tugurejo Kota Semarang. Journal Of Marine Research. Vol 1 No. 2.243-251.

Odum, E. P. 1993. Dasar - Dasar Ekologi. Gramedia. Jakarta. 697 hlm

Poore, C.B. 2004. Marine Decapod Crustacea of Southern Australia : A Guide to Identification. CSIRO. Australia. 617 hal

Pratiwi A. 2002. Studi Struktur Komunitas dan Beberapa Aspek Biologis Makrobentos Krustasea di Komunitas Mangrove Pulau Ajkwa dan Pulau Kamaro Kabupten Mimika Papua.
[Skripsi]. Fakultas Perikanan dan IImu Kelautan Universitas Diponegoro.

Putri, L. S. E., Hidayat, A. F., dan Sukandar, P. 2012. Diversity of Coral Reefs in Badul Island Waters, Ujung Kulon, Indonesia. ISCA Journal of Biological Science, Vol. 1(3) :59-64

Romimohtarto, K. dan Juwana, S. 2009. Biologi Laut: IImu Pengetahuan tentang Biologi Laut. Jakarta. 540 hal.

Santoso, P. 2013. Perbedaan Keanekaragaman dan Kerapatan Jenis Dekapoda pada Karang Mati (Pocillopora Verrucosa dan Riatopora Histrix) di Pulau Pari. Kepulauan Seribu DKI Jakarta. IPB.

Suharsono. 2008. Jenis-jenis karang di Indonesia. LIPI Press. Jakarta. $372 \mathrm{p}$.

UNESCO. 2007. Marine Biodiversity Data Mobilisation Workshop on Decapoda. Ostend. Belgia. No 90

Wedaningsih, R., 2005. Struktur Komunitas Kepiting di Habitat Mangrove Pantai Tanjung Pasir, Tanggerang, Banten [SKRIPSI]. Program Studi IImu Kelautan, Departemen IImu dan Teknologi Kelautan, Fakultas Perikanan dan IImu Kelautan, Institut Petanian Bogor, 98 hal 